\title{
Taxonomic Study of Non-alkaliphilic Halococci
}

\author{
By CARLOS G. MONTERO, ${ }^{1}$ ANTONIO VENTOSA, ${ }^{*}$ FRANCISCO \\ RODRIGUEZ-VALERA ${ }^{2}$ AND FRANCISCO RUIZ-BERRAQUERO ${ }^{1}$ \\ 1 Department of Microbiology, Faculty of Pharmacy, University of Sevilla, Sevilla, Spain \\ ${ }^{2}$ Department of Microbiology, Faculty of Medicine, University of Alicante, Alicante, Spain
}

(Received 5 August 1987; revised 2 November 1987)

\begin{abstract}
Ninety-six extremely halophilic, non-alkaliphilic cocci were isolated from several salterns in different geographical areas of Spain. These strains, together with seven reference strains of the genus Halococcus, were characterized by means of 114 phenotypic features, the results being analysed by numerical techniques using the simple matching $\left(S_{S M}\right)$ coefficient and the unweighted pair group clustering (UPGMA) algorithm. At the $70 \%$ similarity level, four phenons were obtained. Phenon A contained 87 strains, including all the reference strains, and was considered to comprise members of the only named species of the genus Halococcus, $H$. morrhuae. Phenons B and C, which included five and seven strains respectively, showed greater metabolic versatility than phenon $\mathrm{A}$. The four strains belonging to phenon $\mathrm{D}$ were significantly different from the other phenons in that they produced acid from glucose and were able to use most of the organic compounds tested. The results indicate that there is phenotypic diversity among the members of the genus Halococcus and that phenon D may constitute a new taxon.
\end{abstract}

\section{INTRODUCTION}

The family Halobacteriaceae has traditionally been defined as a homogeneous group of extremely halophilic bacteria comprising only two genera: Halobacterium and Halococcus (Larsen, 1984). However, the genus Halobacterium includes species which are very different, both phenotypically and genotypically (Oren, 1983; Rodríguez-Valera et al., 1983; Ross \& Grant, 1985; Tindall \& Trüper, 1986; Torreblanca et al., 1986) and recently, the new genera Natronobacterium, Natronococcus, Haloarcula and Haloferax have been proposed in order to accommodate other examples of extremely halophilic archaebacteria (Tindall et al., 1984; Torreblanca et al., 1986).

That this natural diversity remained unexplored for so long can be attributed to the use of a very restricted variety of culture media and the lack of any systematic isolation of these kinds of organisms from diverse natural saline habitats. The genus Halococcus has received even less attention, and only one species, $H$. morrhuae, is recognized (Kocur \& Hodgkiss, 1973; Larsen, 1984). However, relatively few strains have been studied, because the isolation of halophilic cocci from hypersaline environments is usually more difficult than that of the extremely halophilic rods, due to their low proportion in such natural habitats (Rodríguez-Valera et al., 1985; Márquez et al., 1987). The purpose of this work was to carry out a taxonomic study of a large number of extremely halophilic cocci isolated from several hypersaline habitats and to compare these with appropriate reference strains.

\section{METHODS}

Isolation of strains. The micro-organisms were isolated from ponds of salterns located in Cadiz, Majorca and near Alicante (Spain). Samples were taken at regular intervals from September 1984 to November 1985 (24 samplings from 11 different sites). The $\mathrm{Cl}^{-}$content of the samples (determined using $\mathrm{AgNO}_{3}$ ) was in the range $12 \cdot 7-34 \cdot 7 \%$. For the isolation of the extremely halophilic cocci two methods were used: (i) direct plating on several isolation media; (ii) large water samples (about 5 litres) were centrifuged at $27000 \mathrm{~g}$ for $10 \mathrm{~min}$, resuspended in distilled water for $24 \mathrm{~h}$, and then plated on media, since halophilic cocci survive in distilled water (Rodriguez- 


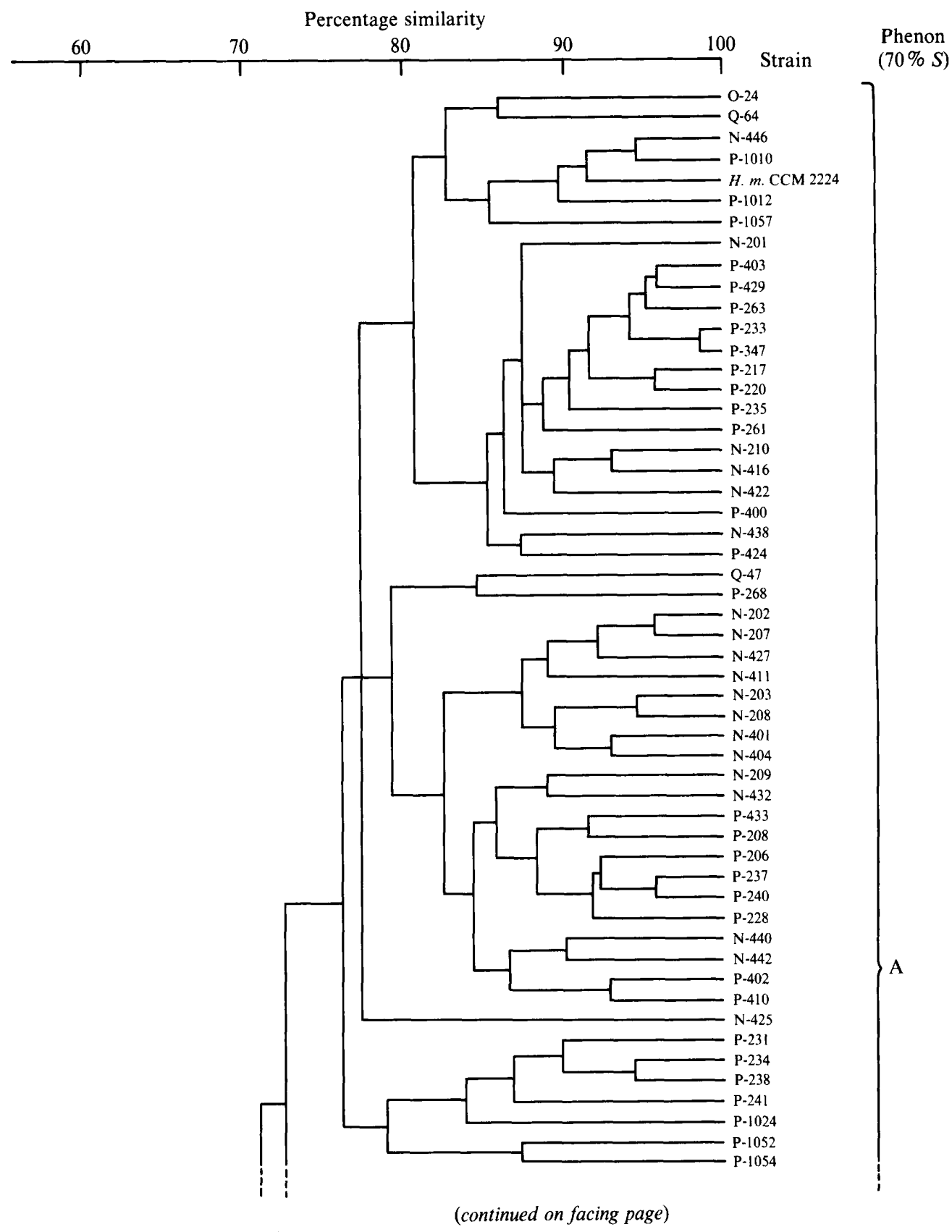

Valera et al., 1982) whereas Halobacterium spp. lyse under these conditions (Brown \& Cho, 1970). Several isolation media were used: HM medium (Ventosa et al., 1982) contained (\%, w/v): yeast extract (Difco), 1; Proteosepeptone no. 3 (Difco), 0.5 ; glucose, 0.1 ; Bacto-agar (Difco), 2. This medium was supplemented with a balanced mixture of sea salts giving a final concentration of $25 \%$ (w/v) (Rodriguez-Valera et al., 1980), and with $500 \mathrm{IU}$ sodium penicillin $\mathrm{G} \mathrm{ml}^{-1}$ in order to inhibit the growth of moderately halophilic and halotolerant eubacteria. Other media used included those previously described by Bertulo (1960-1961) and Eimjhellem (1965), and a defined minimal medium containing $25 \%$ (w/v) final salts concentration (Rodríguez-Valera et al., 1980) and $0.5 \%$ $(\mathrm{w} / \mathrm{v}) \mathrm{NH}_{4} \mathrm{Cl}$, supplemented with $1 \%(\mathrm{w} / \mathrm{v})$ of different substrates (glucose, glutamic acid, sodium acetate, mannitol or xylose). In a second set of experiments, these minimal media were supplemented with $0 \cdot 1 \%(\mathrm{w} / \mathrm{v})$ 


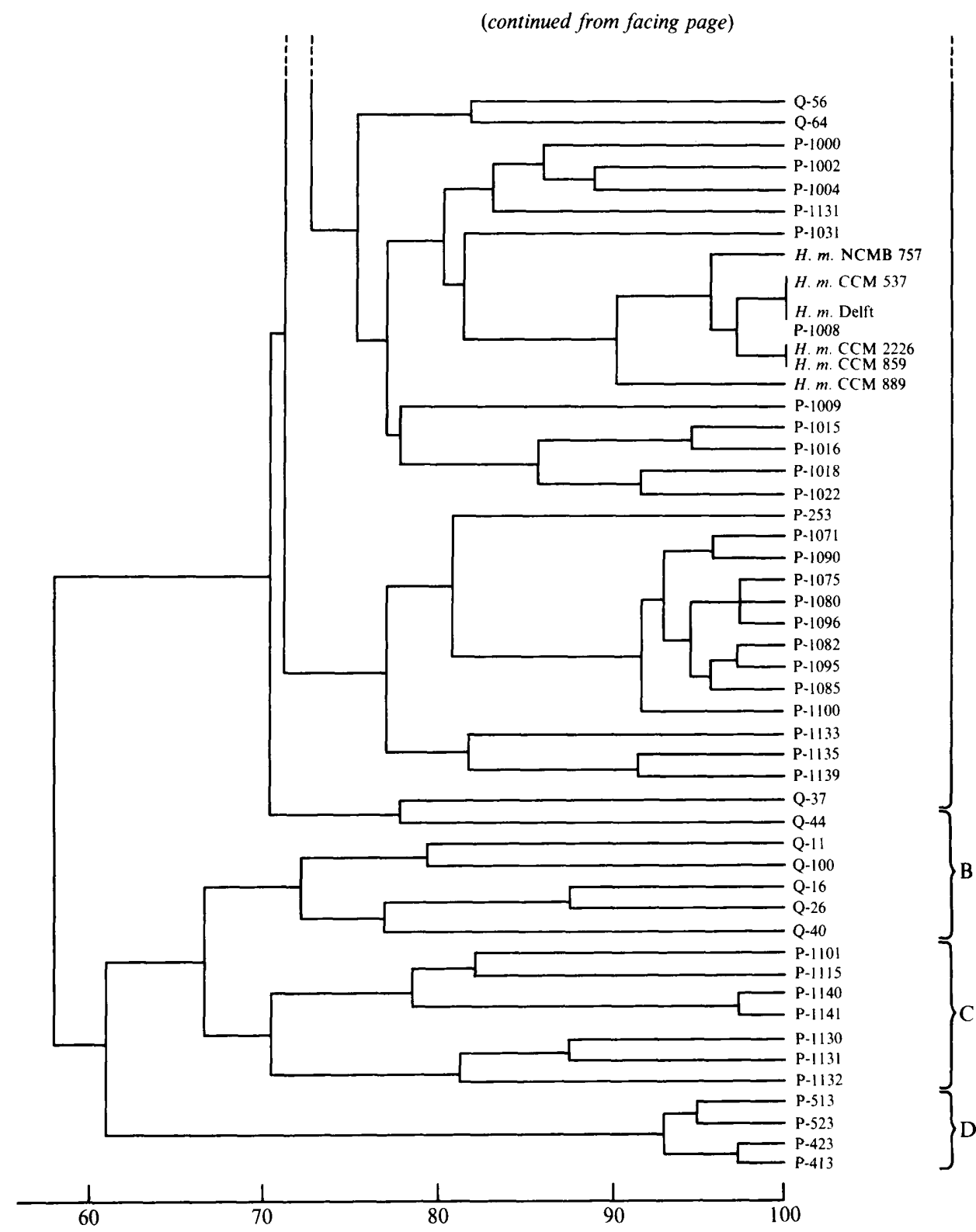

Fig. 1. Dendrogram showing the clustering of the strains based on the $S_{S M}$ coefficient and UPGMA clustering, for 96 extremely halophilic non-alkaliphilic cocci from solar salterns and seven reference strains of Halococcus morrhuae (H. m.).

Casamino acids (Difco) or with $0.01 \%(\mathrm{w} / \mathrm{v})$ of the following amino acids : arginine, methionine, valine, isoleucine, leucine, lysine, glutamine and asparagine (Dundas et al., 1963; Onishi et al., 1965). All media were adjusted to pH $7 \cdot 2$ with I $\mathrm{M}-\mathrm{NaOH}$.

After incubation for $30 \mathrm{~d}$ at $37^{\circ} \mathrm{C}$, and subculturing on the same isolation medium to ensure purity, a total of 96 isolates were selected on the basis of their spherical morphology and extremely halophilic response.

Reference strains. The following extremely halophilic cocci were also included in this study: Halococcus morrhuae strains CCM 537 ${ }^{\top}$, CCM 859, CCM 889, CCM 2224, CCM 2226, NCMB 757 and Delft.

Maintenance medium. The strains were maintained on agar slants of $\mathrm{HM}$ medium with $25 \%(\mathrm{w} / \mathrm{v})$ salts. The $\mathrm{pH}$ was adjusted to $7 \cdot 2$ with $1 \mathrm{M}-\mathrm{NaOH}$. 
Table 1. Frequencies of positive characters found in the four phenons, expressed as a percentage of the total scored to each group for the given test

The differential characteristics of the four phenons are marked with asterisks. Of the 114 characters, 42 turned out to be constant over the 103 strains studied, and these are described in the footnote to this table.

Characteristic

$\begin{array}{cccc}\text { Phenon A } & \text { Phenon B } & \text { Phenon C } & \text { Phenon D } \\ \text { (87 strains) } & \text { (5 strains) } & \text { (7 strains) } & \text { (4 strains) }\end{array}$

Salts, growth at $\%(w / v)$ :

10

$15^{*}$

20

Acid production from:

D-Glucose*

Lactose

D-Mannitol

Indole production

Methyl red

Gelatin hydrolysis

Starch hydrolysis*

Tween 80 hydrolysis

Casein hydrolysis

Phosphatase

DNAase*

$\mathrm{NO}_{3}^{-}$reduction to $\mathrm{NO}_{2}^{-*}$

$\mathrm{NO}_{2}^{-}$reduction to gaseous compounds

Koser's citrate

$\mathrm{H}_{2} \mathrm{~S}$ production from:

Thiosulphate

Cysteine*

Utilization of organic compounds as sole source of carbon and energy:

Carbohydrates:

Aesculin
L-Arabinose*
Amygdalin*
D-Cellobiose
D-Fructose
D-Galactose
D-Glucose
Lactose*
Maltose
D-Mannose
D-Ribose
D-Salicin*
Starch
Sucrose
D-Xylose*
Alcohols:
Adonitol*
Dulcitol
Ethanol
Erythritol
DL-Glycerol*
meso-Inositol
D-Mannitol
Propanol
D-Sorbitol
Carboxylic acids:
Acetate
cis-Aconitate*
$\delta$-Aminovalerate
Fumarate
D-Gluconate*
D-Glucuronate

$\begin{array}{cccc}\text { Phenon A } & \text { Phenon B } & \text { Phenon C } & \text { Phenon D } \\ \text { (87 strains) } & \text { (5 strains) } & \text { (7 strains) } & \text { (4 strains) }\end{array}$

1
62

95

3

1

1

0

92

23

76

5

41

12

86

46

98

16

61
0
100
100

0

0

0
0

100

100

100

0
20

0

20

20

100

60

80

40

80

60

80

80

100

100

20

80

40

40

80

80

100

100

100

60

100

60

100

100

100

100

100

100

0

100

100

0

80

$\begin{array}{rr}0 & 0 \\ 86 & 0 \\ 100 & 100\end{array}$

$0 \quad 100$

$\begin{array}{ll}0 & 0 \\ 0 & 0\end{array}$

$\begin{array}{rr}0 & 0 \\ 0 & 50\end{array}$

$100 \quad 50$

$0 \quad 0$

$86 \quad 0$

$\begin{array}{rr}0 & 0 \\ 71 & 50\end{array}$

$71 \quad 50$

$100 \quad 100$

$71 \quad 50$

$71 \quad 100$

$14 \quad 0$

$100 \quad 100$
0

0

(1)

(

0
0 
Table 1. (continued)

Characteristic
Hippurate*
DL-Lactate
DL-Malate
Pyruvate
Propionate*
Quinate
D-Saccharate
Succinate
Utilization of amino acids as sole source of
carbon, nitrogen and energy:
L-Alanine
L-Arginine
L-Asparagine
L-Aspartic acid
L-Glutamic acid*
L-Isoleucine
L-Leucine
L-Lysine
L-Methionine*
L-Ornithine
DL-Phenylalanine
Sarcosine
L-Serine
L-Threonine
L-Tryptophan*

$\begin{array}{cc}\text { Phenon A } & \text { Phenon B } \\ \text { (87 strains) } & \text { (5 strains) }\end{array}$

$\begin{array}{ll}\text { Phenon C } & \text { Phenon D } \\ \text { (7 strains) } & \text { (4 strains) }\end{array}$

$\begin{array}{rrrr}5 & 0 & 0 & 100 \\ 0 & 20 & 29 & 100 \\ 20 & 20 & 100 & 100 \\ 66 & 80 & 100 & 100 \\ 0 & 0 & 29 & 100 \\ 1 & 20 & 86 & 100 \\ 2 & 40 & 100 & 100 \\ 32 & 40 & 100 & 100\end{array}$

All strains were Gram-negative non-motile cocci, occurring in pairs, tetrads, sarcinae or irregular clusters, formed catalase, and were strict aerobes and oxidase positive. They grew at 25 and $30 \%(\mathrm{w} / \mathrm{v})$ total salts. None of the strains grew at $0,0 \cdot 5,3$ or $5 \%(w / v)$ total salts. All were pigmented pink to brick-red. None produced acid from sucrose, or grew on D-galactosamine, D-glucosamine, inulin, D-melibiose, D-raffinose, L-rhamnose, $\alpha$ aminobutyrate, benzoate, caprylate, $p$-hydroxybenzoate, malonate, oxalate, salicylate, suberate or $D$-tartrate as sole source of carbon and energy. None grew on alantoin, creatinine, ethionine, glycine or putrescine as sole source of carbon, nitrogen and energy. All grew on trehalose, $N$-acetylglucosamine or butyrate as sole source of carbon and energy. All grew on L-glutamine, L-histidine, L-proline or L-valine as sole source of carbon, nitrogen and energy.

Characterization of isolates. For each strain 114 phenotypic characteristics (see Table 1) were determined. The tests have been described previously (Kocur \& Hodgkiss, 1973; Rodriguez-Valera et al., 1983; Torreblanca $e t$ al., 1986). Unless otherwise indicated, all media contained $25 \%(\mathrm{w} / \mathrm{v})$ marine salts and their $\mathrm{pH}$ was adjusted to $7 \cdot 2$ with $1 \mathrm{M}-\mathrm{NaOH}$. Incubation was at $37^{\circ} \mathrm{C}$ for up to $30 \mathrm{~d}$ in sealed containers.

Numerical analysis. Taxonomic characters were coded in binary form of the presence/absence type. Strain similarities were estimated with both simple matching $\left(S_{S M}\right)$ (Sokal \& Michener, 1958) and Jaccard $\left(S_{J}\right)$ (Jaccard, 1908) coefficients, and cluster analysis was carried out using the unweighted pair group method of association (UPGMA) (Sneath \& Sokal, 1973). Test error was estimated in eight replicate strains (Sneath \& Johnson, 1972). Cophenetic correlation was also evaluated (Sneath \& Sokal, 1973). These computations were done using the MINT program of Dr F. J. Rolf (Department of Ecology and Evolution, State University of New York at Stony Brook, NY, USA), on a Univac 1108 computer in the Computer Centre of the University of Sevilla, Sevilla, Spain.

\section{RESULTS}

All the strains of extremely halophilic cocci were isolated by the distilled water selection method. Direct plating without selection did not yield any isolates, presumably because the numbers of organisms were too small compared with those of halobacteria. All solid media gave similar counts and the 96 isolates were picked to try and get the maximum variety with regard to the isolation medium and geographical origin.

The result of the numerical study by means of the $S_{S M}$ coefficient and UPGMA clustering method is shown in the dendrogram (Fig. 1). The cophenetic value was 0.816 and the estimated test error was less than $3 \%$. The cluster composition was not markedly affected by using the $S_{J}$ 
coefficient. At the $70 \%$ similarity $(S)$ level, the strains were grouped into four phenons (A, B, C and D). The phenotypic characteristics of the four phenons are listed in Table 1; their differential characters are marked with asterisks.

Phenon $A$. This group included 87 strains clustered at $71 \% \mathrm{~S}$. It included all the reference strains, except $H$. morrhuae CCM 2224 , as a subphenon at $90 \% S$. The strains were non-motile cocci, strict aerobes, able to hydrolyse gelatin and Tween 80 , and reduced nitrate to nitrite. Acid was not generally produced from glucose or from other sugars. They used a very low number of carbohydrates, alcohols or carboxylic acids as the sole source of carbon and energy. Only some amino acids were utilized, particularly by some strains which formed a subphenon at $92 \% S$. The isolates in this phenon derived from all the sites sampled and they appeared on all the media used.

Phenon $B$. The five strains of this phenon clustered at $72 \% \mathrm{~S}$. They hydrolysed gelatin, starch and Tween 80 , but not casein; DNAase was not produced. Acid was not produced from sugars. They were able to use more compounds than strains in phenon A as the sole source of carbon and energy, particularly with respect to alcohols. The five representatives of this phenon were isolated from Alicante saltern and on HM medium.

Phenon $C$. This phenon comprised seven strains clustered at $71 \% S$. They hydrolysed gelatin, reduced nitrate to nitrite and produced $\mathrm{H}_{2} \mathrm{~S}$ from cysteine; starch and casein were not hydrolysed. They showed a higher nutritional versatility than strains in phenon A. Their main difference from strains of phenon B was their lower capacity to use alcohols, but higher capacity to use other tested compounds. These strains came from the Cádiz saltern; five were isolated on HM medium, one on minimal medium plus xylose and Casamino acids, and one on minimal medium plus sodium acetate and Casamino acids.

Phenon $D$. The four strains of this phenon clustered at $93 \% S$. They were able to produce acid from glucose, but did not hydrolyse starch or Tween 80 . They reduced nitrate to nitrite and produced $\mathrm{H}_{2} \mathrm{~S}$ from cysteine but not from thiosulphate. One of the most noticeable features of the strains of this phenon was their high nutritional versatility: they were able to use a large number of carbohydrates, alcohols and organic acids as sole source of carbon and energy, and amino acids as sole source of carbon, nitrogen and energy (see Table 1), being the only group able to use $c i s$-aconitate as the sole source of carbon and energy. These strains were isolated from the Cádiz saltern on HM medium.

\section{DISCUSSION}

The scarce information available on non-alkaliphilic halococci suggests that they are a very homogeneous group and comprise a single species, Halococcus morrhuae (Larsen, 1984). However, because of the difficulties of isolating extremely halophilic cocci, only a few strains are available. To increase the number of isolates we have used an enrichment method based upon the higher resistance of the halococci to low salt concentrations (Rodríguez-Valera et al., 1982). Most of these new isolates of extremely halophilic cocci grouped in phenon A and were identified as members of the species $H$. morrhuae. Phenons $\mathrm{B}$ and $\mathrm{C}$, because of their higher metabolic versatility, could be considered as Halococcus sp., closely related to $H$. morrhuae.

There have been several previous studies with strains of the genus Halococcus (Kocur \& Hodgkiss, 1973; Colwell et al., 1979; Larsen, 1984; Javor, 1984) and we find some differences when these are compared with our results. In the study by Kocur \& Hodgkiss (1973), most of the results resemble those obtained with our isolates in phenons $\mathrm{A}, \mathrm{B}$ and $\mathrm{C}$, but we obtained different results in regard to the reduction of nitrate to gaseous compounds and the hydrolysis of gelatin, starch and casein. The utilization of a variety of compounds as the only source of carbon and energy, or of carbon, nitrogen and energy, has not been previously reported. We have shown that the nutritional abilities of strains of halophilic, non-alkaliphilic cocci are very heterogeneous, and there are differences between the 'typical' strains of phenon A and those included in phenons B or C. 
Javor (1984) described three strains with characteristics similar to those of phenons B and D. However, our strains used D-mannitol and D-sorbitol as sole source of carbon and energy, in contrast with the results obtained by Javor (1984). Our results for D-glucose, D-fructose, Dgalactose, sucrose, D-ribose, pyruvate, acetate and lactate are in agreement with those of Javor (1984).

Phenon D constitutes a group of strains able to produce acid from glucose, which do not hydrolyse starch or Tween 80 , but which reduce nitrate to nitrite and produce $\mathrm{H}_{2} \mathrm{~S}$ from cysteine. The polar lipid pattern of a representative of this phenon is also different from those of representatives of phenons $\mathrm{A}, \mathrm{B}$ and $\mathrm{C}$, which are identical (unpublished results). There are no previous reports, to our knowledge, of acid being produced from sugars by members of the genus Halococcus, and our findings also differ from previous taxonomic descriptions in demonstrating a remarkably wide nutritional versatility for halophilic, non-alkaliphilic cocci (Larsen, 1984). Phenon D could thus constitute a new taxon. More extensive chemotaxonomic studies are under way to characterize and describe this possible new group of halophilic archaebacterial cocci more fully.

We are grateful to the Computer Centre of the University of Sevilla for their facilities and to M. C. Márquez for her collaboration. This investigation was supported by grants from the Comisión Asesora para el Desarrollo de la Investigación Científica y Técnica and from the Junta de Andalucía.

\section{REFERENCES}

BERTULO, V. H. (1960-1961). La saponina como agente selectivo en la diferenciación de las bacterias rojas halófilas. Anales de la Facultad de Veterinaria de Montevideo 19-22.

Brown, A. D. \& CHo, K. Y. (1970). The walls of the extremely halophilic cocci: Gram-positive bacteria lacking muramic acid. Journal of General Microbiology 62, 267-270.

ColWell, R. R., LitchField, C. D., VREeland, R. H., KIEFER, L. A. \& GibBons, N. E. (1979). Taxonomic studies of red halophilic bacteria. International Journal of Systematic Bacteriology 29, 379-399.

Dundas, I. D., SRinivasan, V. R. \& Halvorson, H. O. (1963). A chemically defined medium for Halobacterium salinarium strain ' 1 '. Canadian Journal of Microbiology 9, 619-624.

EIMJHELLEM, K. (1965). Isolation of extremely halophilic bacteria. Zentralblatt für Bakteriologie, Parasitenkunde, Infektionskrankheiten und Hygiene (Abteilung I) 1, 126-137.

JACCARD, P. (1908). Nouvelles recherches sur la distribution florale. Bulletin de la Societé vaudoise des sciences naturelles 44, 223-270.

JAVOR, B. J. (1984). Growth potential of halophilic bacteria isolated from solar salt environments: carbon sources and salt requirements. Applied and Environmental Microbiology 48, 352-360.

KoCUR, M. \& HodgKISs, W. (1973). Taxonomic status of the genus Halococcus Schoop. International Journal of Systematic Bacteriology 23, 151-156.

LARSEN, H. (1984). Family Halobacteriaceae. In Bergey's Manual of Systematic Bacteriology, vol. 1, pp. 261-267. Edited by N. R. Krieg. Baltimore: Williams \& Wilkins.

Marquez, M. C., Ventosa, A. \& Ruiz-Berraquero, F. (1987). A taxonomic study of heterotrophic halophilic and non-halophilic bacteria from a solar saltern. Journal of General Microbiology 133, 45-56.
Onishi, H., MCCANCE, M. E. \& Gibbons, N. E. (1965). A synthetic medium for extremely halophilic bacteria. Canadian Journal of Microbiology 11, 365-373.

OREN, A. (1983). Halobacterium sodomense sp. nov., a Dead Sea halobacterium with an extremely high magnesium requirement. International Journal of Systematic Bacteriology 33, 381-386.

Rodriguez-Valera, F., Ruiz-Berraquero, F. \& RAMOS-CORMENZANA, A. (1980). Isolation of extremely halophilic bacteria able to grow in defined inorganic media with single carbon sources. Journal of General Microbiology 119, 535-538.

Rodriguez-Valera, F., Ventosa, A., Quesada, E. \& Ruiz-Berraquero, F. (1982). Some physiological features of Halococcus sp. at low salt concentrations. FEMS Microbiology Letters 15, 249-252.

RoDriguez-VAlera, F., Juez, G. \& Kushner, D. J. (1983). Halobacterium mediterranei sp. nov., a new carbohydrate-utilizing extreme halophile. Systematic and Applied Microbiology 4, 369-381.

Rodriguez-Valera, F., Ventosa, A., Juez, G. \& IMHOFF, J. F. (1985). Variation of environmental features and microbial populations with salt concentrations in a multi-pond saltern. Microbial Ecology 11, 107-115.

Ross, H. N. M. \& Grant, W. D. (1985). Nucleic acid studies on halophilic archaebacteria. Journal of General Microbiology 131, 165-173.

SNEATH, P. H. A. \& Johnson, R. (1972). The influence on numerical taxonomic similarities of error in microbiological tests. Journal of General Microbiology 72, 377-392.

SNeath, P. H. A. \& Sokal, R. R. (1973). Numerical Taxonomy. The Principles and Practice of Numerical Classification. San Francisco: Freeman.

SoKal, R. R. \& Michener, C. D. (1958). A statistical method for evaluating systematic relationships. University of Kansas Science Bulletin 38, 1409-1438. 
Tindall, B. J., Ross, H. N. M. \& Grant, W. D. (1984). Natronobacterium gen. nov. and Natronococcus gen. nov., two new genera of haloalkaliphilic archaebacteria. Systematic and Applied Microbiology 5, 41-57.

TINDALl, B. J. \& TRÜPER, H. G. (1986). Ecophysiology of the aerobic halophilic archaebacteria. Systematic and Applied Microbiology 7, 202-212.

TORReblanca, M., Rodriguez-Valera, F., Juez, G., Ventosa, A., Kamekura, M. \& Kates, M. (1986).
Classification of non-alkaliphilic halobacteria based on numerical taxonomy and polar lipid composition, and description of Haloarcula gen. nov. and Haloferax gen. nov. Systematic and Applied Microbiology 8, 89-99.

Ventosa, A., Quesada, E., Rodriguez-Valera, F., Ruiz-BerraQuero, F. \& Ramos-Cormenzana, A. (1982). Numerical taxonomy of moderately halophilic Gram-negative rods. Journal of General Microbiology 128, 1959-1968. 